\title{
Municipal Liability and Police Training for MENTAL ILLNESS: Causes of ACtion and Feasible Solutions
}

\author{
Andrew C. Hanna* \\ TABLE OF CONTENTS
}

I. INTRODUCTION ..................................................222
A. The Issue .223

B. Roadmap

227

II. BACKGROUND.........................................................228

A. Law Enforcement as First Responders ...............228

B. Deinstitutionalization..........................................232

C. Current Police Training for Mental Illness .........234

D. Deadly Consequences .......................................236

III. MuniCIPAL LIABILITY ...............................................238

A. The Americans with Disabilities Act ("ADA") ....238

1. Causes of Action Under Title II of the ADA ..240

a. Wrongful arrest.....................................241

b. Reasonable accommodation during arrest

c. Failure-to-train .....................................245

2. Department of Justice ADA Enforcement ......247

B. $\$ 1983$ Causes of Action Under the U.S.

Constitution ............................................................248

1. Municipal Liability Under $\$ 1983$.................248

* J.D. Candidate, 2017, Indiana University Robert H. McKinney School of Law; B.A., 2014, Hanover College; Reserve Police Officer for the Elwood Police Department from 2012-2016. I would like to thank Professor Florence Wagman Roisman for her inspiration of this Note and Mary Lawrence Phillips for her patience, kindness, and support. I would also like to thank my fellow members of the Indiana Health Law Review, my friends and former colleagues at the Elwood Police Department and Professor Ken Falk, Dr. Mark Kane, Dr. Richard T. DuPont, Lt. Ret. Michael Woody, and Sheriff Scott Mellinger for their contributions to this Note. Any errors are entirely of my own making.

http://doi.org/10.18060/3911.0039 
2. Failure-to-train ...........................................250

3. Indemnification of Excessive or Unreasonable Force Claims..............................................253

IV. A FeAsible Solution..............................................255

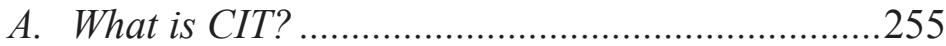

B. CIT Officers ....................................................257

C. Results of Implementing CIT Training................260

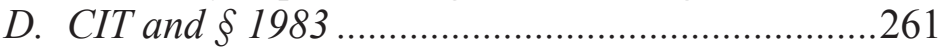

V. CONCLUSION.............................................................264

\section{INTRODUCTION}

Teresa Sheehan was "liv[ing] in a group home for individuals with mental illness."1 On August 7, 2008, Sheehan began to act erratically and threatened to kill her social worker. ${ }^{2}$ When the social worker contacted the City and County of San Francisco Police Departments ("San Francisco"), two police officers were dispatched to the scene. ${ }^{3}$ Upon the officers' arrival, they were asked to assist Sheehan's social worker in bringing Sheehan to a facility for temporary evaluation and treatment. ${ }^{4}$ However, when officers confronted Sheehan in her room, she brandished a knife and threatened to kill them. ${ }^{5}$ In response to Sheehan's threat, the officers retreated from the room and shut the door. ${ }^{6}$ Fearful of what Sheehan would do behind the closed door, the officers reentered the room and used pepper spray in an attempt to overwhelm Sheehan. ${ }^{7}$ After the pepper spray

${ }^{1}$ City and Cty. of S. F., Cal. v. Sheehan, 135 S.Ct. 1765, 1767 (2015).

${ }^{2} I d$. at 1767,1769 .

${ }^{3} I d$. at 1767,1770 .

${ }^{4} I d$. at 1767.

${ }^{5} \mathrm{Id}$. at $1767-68$.

${ }^{6} \mathrm{Id}$. at 1768 .

${ }^{7} \mathrm{Id}$. 
proved ineffective, and without taking additional action in order to accommodate her disability, the officers shot Sheehan multiple times. ${ }^{8}$

Teresa Sheehan's case is not an isolated incident of police interaction with individuals with mental illness; rather, it is a common occurrence and one that ends all too frequently in violence. ${ }^{9}$ Media scrutiny surrounding policeaction shootings involving similarly alarming factual situations has contributed to a national dialogue as to what training police officers, who are often the first responders to incidents involving individuals with mental illness, receive, and how our society can improve such training and reduce the number of cases that result in bloodshed.

\section{A. The Issue}

This Note examines the current state of mental health training for law enforcement officers around the country, training programs that have proven successful for law enforcement agencies, and municipal liability as a result of failing to provide such training. This Note is intended to serve as a valuable addition to a national dialogue surrounding individuals with mental illness and the responsibility that our law enforcement officers carry when dealing with such individuals.

\footnotetext{
${ }^{8} I d$.

9 David D. Perry \& Lawrence Carter-Long, The Ruderman Family Found., The Ruderman White Paper in Media Coverage OF LAW ENFORCEMENT USE OF FORCE AND Disability: A MEDiA STUDY (2013-2015) AND OVERVIEW (2016) (concluding that "disabled individuals" make up a third to half of all people killed by law enforcement and a majority of those killed in incidents that garner widespread media attention).
} 
The term "individuals with mental illness" as utilized in this Note covers a variety of mental health diagnoses. ${ }^{10}$ In general, "[a] mental illness is a condition that impacts a person's thinking, feelings or mood and may affect his or her ability to relate to others and function on a daily basis." 11 These diagnoses include, but are not limited to, AttentionDeficit/Hyperactivity Disorder (“ADHD”), Anxiety Disorders, Autism, Bipolar Disorder, Borderline Personality Disorder, Depression, Dissociative Disorders, Obsessivecompulsive Disorder, Posttraumatic Stress Disorder ("PTSD"), Schizoaffective Disorder and Schizophrenia. ${ }^{12}$ Symptoms of mental illnesses vary drastically and "even people with the same diagnosis" often display different symptoms. ${ }^{13}$ These symptoms can consist of sadness, extreme mood swings, paranoia, hallucinations, comprehension difficulties, alcohol or drug abuse, suicidal tendencies, excessive anger, hostility or violence. ${ }^{14}$ Approximately 61.5 million Americans, or one in four adults, have a mental illness. ${ }^{15}$ However, because the burden of illness is "particularly concentrated among those who

10 The author encourages the use of the term "disability" when referring to individuals with mental illness because "[d]isability carries important legal and cultural connotations about identity, accommodation, and inclusion." Id. at 41.

11 Mental Health Conditions, National Alliance on Mental ILLNESS, https://www.nami.org/Learn-More/Mental-Health-Conditions (perma.cc/9JYW-97CJ) (last visited January 3, 2015).

${ }^{12} \mathrm{Id}$.

${ }^{13}$ Id.

14 Mental Illness: Symptoms, MAYO Clinic, http://www.mayoclinic.org/diseases-conditions/mentalillness/basics/symptoms/con-20033813 (last visited Nov. 3, 2015) [perma.cc/2KLS-TCRC].

15 Mental Illness Facts and Numbers, NATIONAL AllianCE ON MENTAL ILLNESS (2013),

http://www2.nami.org/factsheets/mentalillness_factsheet.pdf [perma.cc/D78Z-PWFR]. 
experience disability due to serious mental illness ("SMI")," which is roughly defined as a mental illness that "substantially interferes with or limits one or more major life activities," 16 this is the general definition employed by this Note. As of 2014, one in twenty-five adults had a SMI. ${ }^{17}$

This topic is important for many reasons. First, it is one of great everyday significance for those Americans who struggle with mental illness. Given the symptoms of many mental illnesses, particularly SMI, and the propensity of individuals with mental illness to be victims of crimes, these individuals have an increased likelihood of coming into contact with the police. ${ }^{18}$ Second, development of this topic will be of great importance to law enforcement agencies that are attempting to increase their officers' preparedness in order to properly deal with individuals with mental illness. ${ }^{19}$ Third, it will be helpful to law enforcement agencies that wish to minimize their liability from several causes of action stemming from violations of the Americans with Disabilities Act ("ADA") and/or the United States Constitution. Fourth, given the current state of the law and a lack of definitive

16 Mental Health By The Numbers, NATIONAL Alliance ON MENTAL ILLNESS, https://www.nami.org/Learn-More/Mental-HealthBy-the-Numbers (last visited Jan. 3, 2015) [perma.cc/WFN8-GNBV].

17 Mental Illness Facts and Numbers, NATIONAL Alliance ON MENTAL ILLNESS

(2013), http://www2.nami.org/factsheets/mentalillness_factsheet.pdf [perma.cc/D78Z-PWFR] (1 in 25 adults, or approximately 10 million, or $4.2 \%$ of the adult U.S. population).

18 Victimization of People with Mental Illness, Mental ILlness POLICY ORG. http://mentalillnesspolicy.org/consequences/victimization.html (last visited November 1, 2015) [perma.cc/EYH4-YCGJ].

${ }^{19}$ Michael Anthony Adams, Mental Illness and Police, and the State

of Crisis Intervention in Indianapolis, (Sept. 13, 2015), http:/www.indystar.com/story/news/crime/2015/09/14/killing-alexmyers-state-crisis-intervention-indianapolis/72090136/ [perma.cc/3VL8-BCK9]. 
rulings from the Supreme Court, this topic is likely to receive continued attention by both attorneys and judges that will inevitably follow. Finally, with increased media attention surrounding mental health and nationally divisive events regarding encounters between the police and individuals with mental illness, this topic is also likely to remain in the spotlight for years to come.

Individuals with mental illness can present unique challenges for law enforcement officers as they come into contact around the community. Oftentimes, these individuals react differently to confrontations with the police and can also react adversely to traditional police training. Unfortunately, many police officers are drastically undertrained when it comes to dealing with individuals with mental illness. ${ }^{20} \mathrm{~A}$ basic lack of understanding and absence of alternative problem-solving techniques can increase the likelihood that a police officer will resort to deadly force in order to eliminate a perceived threat. ${ }^{21}$ Across the country, there are undoubtedly countless situations that could have ended in a less violent, viable alternative, had an officer received adequate mental health training.

As a former police officer myself, I realize the unique challenges posed by interacting with individuals with mental illness. I also realize the significant challenges that police departments face when forced to prioritize training because of limited and often insufficient funding. Between my father, my grandfather, and myself, we have accumulated over

${ }^{20}$ For instance, Indiana law only mandates that law enforcement training include a minimum of six (6) hours of training that includes "mental illness." However, the six (6) hours also includes autism, addictive disorders, intellectual disabilities, developmental disabilities, missing endangered adults, and persons with Alzheimer's disease or related dementia. Ind. Code § 5-2-1-9(9)(a)-(c).

${ }^{21}$ Amy Watson et al., Improving Police Response to Persons with Mental Illness: A Multi-level conceptualization of CIT, 31 Int J Law Psychiatry 359-68 (2008). 
sixty-five years of law enforcement experience. ${ }^{22}$ Suffice it to say, I maintain the highest respect and regard for the law enforcement community. I also believe that law enforcement should be held to high standards. After all, law enforcement is, in a very real way, the government in the streets. We have a constitutional and moral duty to handle suspects in the least violent way possible. In order to confront the specific challenges that individuals with mental illness pose, and to prioritize safety for both police and citizens, proper mental health training is an absolute necessity.

\section{B. Roadmap}

This Note will be founded in case law from various jurisdictions, numerous secondary sources, applicable federal statutory law, and the Constitution of the United States. Summarily, it will attempt to answer these three important questions: what are police doing when they interact with individuals with mental illness? What does U.S. Constitution and federal law require of police when interacting with individuals with mental illness? And, what innovative training programs should police departments utilize in order to reduce potential liability and, more importantly, reduce the likelihood of violent confrontations?

In order to facilitate a better understanding of the current state and frequency of police interaction with individuals with mental illness, Section II discusses general background information pertinent to such a discussion. This includes a

${ }^{22}$ Myself: 4 years as a reserve police officer with the Elwood Police Department; Sam Hanna (Father): 37 years with the Madison County Sheriff's Department; 3 years with other law enforcement agencies serving in various capacities and was shot six times from point-blank range in 1978 (I mention this only to reiterate that I fully understand and appreciate the life and death consequences police officers face on the beat every day, in every community around the country); Jim Hanna (Grandfather): 23 years with the Anderson Police Department. 
brief discussion of deinstitutionalization and an overview of current police training and the types of situations that police officers face when interacting with individuals with mental illness. Section III discusses potential municipal liability for a municipality's failure to train its officers to effectively interact with individuals with mental illness and/or the potential municipal liability for instances where their officers use excessive or unreasonable force against individuals with mental illness. Section III includes a discussion of Title II of the Americans with Disability Act ("ADA") as well as causes of action arising under the Constitution of the United States utilizing 42 U.S.C. § 1983. Section IV discusses a feasible solution to municipal liability — Crisis Intervention Teams ("CIT")—and explains how CIT works, its components and its effectiveness for agencies that have employed the training. Finally, Section V argues for police departments to utilize CIT training or similar de-escalation training and concludes that municipalities should be held liable when they fail to provide adequate training to their police officers.

\section{BACKGROUND}

\section{A. Law Enforcement as First Responders}

Law enforcement officers come into contact with individuals with mental illness for a variety of reasons. In total, a conservative estimate is that $10 \%$ of current police calls involve an individual with mental illness. ${ }^{23}$ According

${ }^{23}$ Amy Watson and Beth Angell, The Role of Stigma and Uncertainty in Moderating the Effect of Procedural Justice on Cooperation and Resistance in Police Encounters with Persons With Mental Illness, 19 Psychol. PUB. POL’y \& L. 30, (Feb. 2013). 
to one Texas study, ${ }^{24}$ the top seven reasons for these interactions were:

1. Family, friends or other concerned persons calling the police for assistance during a psychiatric crisis.

2. Individuals with mental illness feeling suicidal and calling the police as a cry for help.

3. Street encounters with an individual with mental illness behaving inappropriately.

4. Citizens calling the police because they felt threatened by unusual behavior or the mere presence of an individual with mental illness.

5. Individuals with mental illness calling the police for assistance because imaginative threats exist.

6. Individuals with mental illness as the perpetrator of a crime.

7. Individuals with mental illness as the victim of a crime or accident.

Individuals with mental illness, whether they are a suspect, witness or victim pose a unique challenge for law enforcement officers who are often unfamiliar with their particular symptoms, behavior, and demeanor. ${ }^{25}$ With such a wide variety of mental illnesses and symptoms, it is difficult for law enforcement to detect and effectively interact with varying types of mental illness. ${ }^{26}$

\footnotetext{
${ }^{24}$ Leonard W. Peck, Jr., Law Enforcement Interactions with Persons with Mental Illness, TelemasP Bulletin, (Jan/Feb 2003), http://www.lemitonline.org/publications/telemasp/Pdf/volume\%2010/v ol10no1.pdf [https://perma.cc/U8F7-87YM] (summarizing a survey of 35 Texas police departments and six sheriff's departments about their interactions with individuals with mental illness).

${ }^{25} \mathrm{Id}$.

${ }^{26}$ Linda Teplin, Keeping the Peace: Police Discretion and Mentally Ill Persons, National Institute OF JustiCe JournaL, July 2000, at 12
} 
Contrary to popular belief, individuals with mental illness are not more likely to be violent. ${ }^{27}$ They are however, more likely to be victims of violent crimes. ${ }^{28}$ Statistics show that the majority of encounters between law enforcement and individuals with mental illness occur when they are suspected of "committing low-level, misdemeanor crimes, or who are exhibiting nuisance behavior." ${ }^{29}$ In these cases, evidence suggests that persons exhibiting signs of mental illness, ceteris paribus, were more likely to be arrested for the same offense than those showing no signs at all. ${ }^{30}$

Not only are individuals with mental illness more likely to be arrested, they also tend to stay longer in jail. ${ }^{31}$ For example, the Vera Institute of Justice found that in Los Angeles, users of the Department of Mental Health's services spent, on average, twice as much time in custody than members of the general population. ${ }^{32}$ While statistics on the incarceration rate and length of incarceration of individuals with mental illness can be shocking, there is little evidence to suggest that police are biased against individuals

27 Melissa ReUland ET AL., LAW ENFORCEMENT RESPONSES TO PEOPle With Mental Illness: A GuIdE TO RESEARCH-INFORMED PoliCY AND PRACTICE, (Council of State Governments Justice Center, 2009), https://csgjusticecenter.org/wp-content/uploads/2012/12/leresearch.pdf [perma.cc/D7NZ-UAR7].

${ }^{28}$ Richard Van Dorn et al., Community Violence Perpetration and Victimization of Adults with Mental Illness, 104 AMERICAN JOURNAL OF Public Health 2342, 2344 (Dec. 2014).

${ }^{29}$ Reuland, supra note 28.

30 Teplin, supra note 27 (In one study, the probability of being arrested was 67 percent greater for suspects exhibiting signs of a mental disorder than for those who apparently were not mentally ill).

${ }^{31}$ RAM SUBRAMANIAN ET AL., INCARCERATION'S FRONT DOOR: THE Misuse OF JAILS IN AMERICA, 12 (Vera Institute of Justice: Center on Sentencing and Corrections, Feb. 2015), http://www.vera.org/sites/default/files/resources/downloads/incarcerati ons-front-door-report.pdf [perma.cc/CWJ2-Y3LB].

${ }^{32} I d$. 
with mental illness. ${ }^{33}$ Rather, one explanation for this disparity is "mercy bookings." 34 Because individuals with mental illness are "often poor, homeless, and likely to have co-occurring substance use disorders and, thus when untreated, are far more prone to the kinds of public order offenses and minor crimes that have been the focus of law enforcement in recent years and have helped swell jail populations." 35 "Mercy bookings" are utilized when officers arrest individuals exhibiting signs of mental illness in order to "ensure that arrestees would obtain 'three hots and a cot' (i.e., warm meals and a place to sleep, particularly in extreme weather conditions)." 36

Individuals with mental illness comprise a disproportionate percentage of incarcerated individuals across the country. The U.S. Department of Justice estimated that $20 \%$ of state prisoners and occupants of local jails had a "recent history" of a mental health condition and more than half of all prisoners have a mental health problem. ${ }^{37}$ For juveniles in justice systems, over $70 \%$ have at leave one mental health condition. ${ }^{38}$ These situations are often compounded by the fact that individuals with a mental

${ }^{33}$ Arthur J. Lurigio, Examining Prevailing Beliefs About People with Serious Mental Illness in the Criminal Justice System, 75 FED. PROBATION 15, 16 (June 2011) www.uscourts.gov/file/3530/download [perma.cc/VDT4-NLSX].

${ }^{34} I d$.

${ }^{35}$ SUBRAMANIAN ET AL., supra note 32; Although adequate housing and healthcare are outside the focus of this Note, I would be remiss if I did not mention how far those basic necessities (some would argue rights) would go in terms of reducing the frequency of police interaction with individuals with mental illness.

${ }^{36}$ Lurigio, supra note 34.

37 Doris J. James \& Lauren E. Glaze, Mental Health PROBlems of PRISON AND JAIL INMATES, 1 (Bureau of Justice Statistics, 2006), $\quad$ http://bjs.ojp.usdoj.gov/content/pub/pdf/mhppji.pdf [perma.cc/B3MG-F8NX].

${ }^{38}$ National Alliance On Mental ILlNEss, supra note 14. 
illness are more likely to have a substance abuse disorder as well. ${ }^{39}$ Of those in jail or prison, $72 \%$ have a mental illness also suffer from a substance abuse disorder. ${ }^{40}$

\section{B. Deinstitutionalization}

The move to deinstitutionalize individuals with mental illness has contributed greatly to the number of their encounters with the police. ${ }^{41}$ As a result of deinstitutionalization, from 1955 to 1980, the resident population of mental health facilities fell from 559,000 to $154,000 .{ }^{42}$ In 1955 there was one bed in a psychiatric ward for every 300 Americans compared to one for every 3,000 today. ${ }^{43}$ With fewer psychiatric beds available in hospitals across the country and many individuals either being denied treatment or unable to secure adequate funding for treatment, police officers are increasingly relied upon by the families of individuals with mental illness to respond to crises arising

\footnotetext{
39 SUBRAMANIAN ET AL., supra note 32.

${ }^{40} \mathrm{Id}$.

${ }^{41}$ Teplin, supra note 27 ("A number of mental health professionals have commented on what some observers believe is the 'criminalization of mentally disordered behavior' and have speculated that persons who previously were treated within the mental health system increasingly are being shunted into the criminal justice system").

${ }^{42}$ Chris Koyanagi, Kaiser COMmission On MedicAid AND THE Uninsured, LEARNING FROM HiSTORY: DEINSTITUTIONALIZATION OF People with Mental Illness As Precursor to long-Term Care REFORM (Aug. 2007), https://kaiserfamilyfoundation.files.wordpress.com/2013/01/7684.pdf [perma.cc/W3NC-L7KD].

43 Nicholas Kristof, Inside a Mental Hospital Called Jail, N.Y. TIMES (Feb. 8, 2014), http://www.nytimes.com/2014/02/09/opinion/sunday/inside-a-mentalhospital-called-jail.html?_r=0 [perma.cc/ES6T-MJTD].
} 
from a mental illness. ${ }^{44}$ Their families are often "illequipped and poorly supported to meet their needs." 45 Because community health programs meant to replace institutionalization were either inadequate or lacked sufficient funding, ${ }^{46}$ for many, "[t]he default hospital has become the emergency room." 47 Even when community health programs are available, many individuals either lack coverage within their insurance or lack coverage completely. ${ }^{48}$ Nearly a third of individuals with mental illness were either denied coverage by an insurance company or an insurance company deemed such care not medically necessary, and a staggering number of people have not sought care at all. ${ }^{49}$ This inadequacy in health care has led mental health professionals to assert that persons who would previously have been treated within the mental health system are being dealt with by the criminal justice system instead. ${ }^{50}$

Deinstitutionalization, inadequate health care, and other contributing factors have created a system where jails are the

44 INT'L ASS'N OF CHIEFs OF POLICE, BUILDING SAFER Communities: Improving Police Response to Persons With MENTAL ILLNESS (2010), http://www.theiacp.org/portals/0/pdfs/ImprovingPoliceResponsetoPers onsWithMentalIllnessSummit.pdf [perma.cc/Y8AA-YZT2].

${ }^{45}$ Koyanagi, supra note 43.

${ }^{46}$ See id.

${ }^{47}$ Megan Pauly, How Police Officers Are (or Aren't) Trained in Mental Health, THE ATLANTIC (Oct. 11, 2013), http://www.theatlantic.com/health/archive/2013/10/how-policeofficers-are-or-aren-t-trained-in-mental-health/280485/ [https://perma.cc/9ER3-PRLN].

${ }^{48}$ Kimberly Leonard, Patients with Mental Illness No Better Off Under

Obamacare, U.S. NEWS (Apr. 1, 2015, 12:01 AM), http:/www.usnews.com/news/articles/2015/04/01/health-insurancecoverage-discrimination-mental-illness [perma.cc/SFW9-Y6TA].

${ }^{49}$ Id.

50 Teplin, supra note 27. 
largest mental health centers in America and police officers, by in large, are charged with dealing with individuals with mental illness. ${ }^{51}$

\section{Current Police Training for Mental Illness}

Police training is a matter of state law and is often delegated to a board or commission in order to establish specific requirements. ${ }^{52}$ Police officers train in over 650 police academies across the country and receive about nineteen (19) weeks of training. ${ }^{53}$ Most receive a minimum of 400 hours of basic training while exceptionally welltrained officers receive 800 hours of basic training. ${ }^{54}$ After completion of basic training, all states require officers to undergo additional in-service training throughout their career. ${ }^{55}$ This training can consist of general training hours or specific training subjects. ${ }^{56}$

For mental health training, hours vary dramatically from state to state ${ }^{57}$ and even between counties and municipalities

${ }^{51}$ Kristof, supra note 44 (noting that nationwide, more than three times as many mentally ill people are housed in prisons and jails as in hospitals).

${ }^{52}$ Patrick L. Bradley, $21^{\text {st }}$ Century Issues Related to Police Training and Standards, 72 THE POLICE CHIEF (Oct. 2005), http://www.policechiefmagazine.org/magazine/index.cfm?fuseaction=d isplay_arch\&article_id=724\&issue_id=102005 [perma.cc/C5B7-J3S6].

${ }^{53}$ BRian A. REAves, U.S. DEP'T OF Justice, StATE AND Local LAW ENFORCEMENT TRAINING ACADEMIES, 2006, at 1 (2009), http://www.bjs.gov/content/pub/pdf/slleta06.pdf [https://perma.cc/BG45-SEN7].

54 Terry D. Edwards, State Police Basic Training Programs: An Assessment of Course Content and Instructional Methodology, 12 AM. J. OF POLICE 4, 23, 2-5 (1993).

55 Bradley, supra note 53.

${ }^{56} \mathrm{Id}$.

57 Pauly, supra note 48. 
within a state. ${ }^{58}$ States range from Hawaii, where officers are required to obtain 0 hours of mental health training to Florida, where officers are required to gain 40 hours of mental health training while still in the police academy. ${ }^{59} \mathrm{In}$ conjunction with state training, many agencies require additional hours through departmental policy. ${ }^{60}$ While most departments see the merit of mental health training, many lack essential funding in order to provide additional training. ${ }^{61}$ Departments have a wide variety of responsibilities and training requirements, so however important they view mental health training, departments are under competing pressures for varying training programs and, "can't afford to train everyone." 62 The cost of the actual mental health training is relatively low compared to the cost in man-hours ${ }^{63}$ but for many departments, the biggest challenge is taking officers off the street in order for them to attend training and having to pay overtime in order to fill

58 Ashley Remkus, Local Police Training on Mental Health Training Varies, DECATUR DAILY (July 12, 2015), http://www.decaturdaily.com/news/lawrence_county/local-policetraining-on-mental-health-varies/article_71f9d131-7abe-5817-a307e87b588835e4.html [https://perma.cc/R7QL-MY5Q].

59 Pauly, supra note 48 (In a later interview I conducted with Michael Woody - who collected the data in 2010 - he noted that upon further examination of the curriculum in Florida, 40 hours covered the whole spectrum of disabilities- not just mental illness- and that admittedly states have increased mental health training since his findings in 2010).

${ }^{60}$ Remkus, supra note 59.

61 Pauly, supra note 48.

${ }^{62} \mathrm{Id}$.

63 Telephone interview with Sheriff Scott Mellinger, Madison County (Indiana) Sheriff's Department and former Director of the Indiana Law Enforcement Academy ("ILEA") (Jan. 7, 2016) ("[t]he training itself is very inexpensive depending on how you want to run the class. Facilitating the training, having small gifts for presenters and refreshments, those are about the only costs."). 
shifts. ${ }^{64}$ This is especially expensive and cost-prohibitive for smaller departments. ${ }^{65}$

\section{Deadly Consequences}

As more individuals with mental illness come into contact with police officers and police departments struggle to acquire adequate training, results can be deadly. Recent data from the first six months of 2015 shows that of the 462 people killed by police, 124 were "in the throes of mental or emotional crisis." 66 In most of these incidences, police weren't contacted in response to a crime. ${ }^{67}$ Rather, most calls involved family or caretakers calling the police because of an escalating situation. ${ }^{68}$ With the lack of inpatient beds and facilities, families often only rely on the police when a situation has escalated to a dangerous point. ${ }^{69}$ These types of interactions are so common that police officers have been

${ }^{64}$ See id.; See also Joe Smydo \& Rich Lord, Data Shows Police Lack Crisis Intervention Team Training to Deal With Mentally Ill, PitTSBurg Post-GazetTe (Mar. 6, 2016), http://www.postgazette.com/news/health/2016/03/06/Pittsburgh-police-lack-CrisisIntervention-Team-training-to-deal-with-mentallyill/stories/201603060029 [https://perma.cc/XQ69-WW2B] (Mt. Oliver Police Chief Matt Juzwick)(“Once I'm back up to full staff, I could spare somebody. But right now, there's no way I could do it. . . [i]f I paid 40 hours overtime [to cover for an officer in] training, council would have my butt.").

${ }^{65}$ Mellinger, supra note 64.

${ }^{66}$ Wesley Lowery et al., Distranght People, Deadly Results, THE WASH. POST (June 30, 2015), http://www.washingtonpost.com/sf/investigative/2015/06/30/distraught -people-deadly-results/ [https://perma.cc/AWA7-YQJS].

${ }^{67}$ See id.

${ }^{68}$ See id.

${ }^{69}$ Telephone Interview with Michael Woody, President of CIT International, (Jan. 6, 2015). 
dubbed "street corner psychiatrists." 70 More than half of the shootings involved departments that had not provided training for dealing with the mentally ill to their officers. ${ }^{71}$

When confronted by irrational and often unpredictable behavior, officers' responses vary from de-escalation to useof-force. Relying on use-of-force, "[a] police officer is privileged to use the amount of force that the officer reasonably believes is necessary to overcome resistance to his lawful authority, but no more."72 Traditional police training also teaches police to control situations by demanding compliance, and the often unpredictable nature of an individual with mental illness can be misinterpreted as a threat and quickly escalate to violence. ${ }^{73}$ This traditional training is often counterproductive when dealing with individuals who have mental illness and instead of deescalating a situation, it can increase the likelihood of a violent response. ${ }^{74}$

Individuals with mental illness face the greatest risk of injury or death during their encounters with law enforcement because during mental health crises, individuals are often shot or beaten due to their inability to follow police orders. ${ }^{75}$

${ }^{70}$ Watson \& Angell, supra note 24.

${ }^{71}$ Lurigio, supra note 34.

72 Camille A. Nelson, Racializing Disability, Disabling Race: Policing Race and Mental Status, 15 Berkeley J. Crim. L. 1, Spring 2010.

${ }^{73}$ Liza Lucas, Changing the Way Police Respond to Mental Illness, CNN (July 6, 2015), http://www.cnn.com/2015/07/06/health/policemental-health-training/ [perma.cc/HND8-LN84].

74 Aaron Ernst, How Lack of Police Training Can be Deadly for the Mentally Ill, AlJAZEERA AM. (Apr. 23, 2014), http://america.aljazeera.com/watch/shows/americatonight/articles/2014/4/23/how-traditional-

policinghurtsaandsometimeskillsathementallyill.html [perma.cc/577JBEJX].

${ }^{75}$ Rachel Aviv, Letter from Albuquerque: Your Son is Deceased, NEW YORKER (Feb. 2, 2015), 
Because of the particular challenges that individuals with mental illness create and law enforcement's unfamiliarity with such symptoms, verbal abuse and belligerence are often misunderstood as disrespect and may "...provoke an officer to respond more punitively." "W6 While no amount training can effectively eliminate police-action shootings or other use-offorce situations, mental health training can play a pivotal role in altering an officer's response to confrontations with individuals with mental illness and in many cases provide a more peaceful result.

\section{MUNICIPAL LIABILITY}

There are two main avenues for individuals with mental illness to bring suit against law enforcement agencies for either excessive or unreasonable force incidents or a department's failure to train its officers for effective interaction with individuals with mental illness. Those include the ADA and/or a claim arising under the Constitution of the United States utilizing 42 U.S.C. § 1983.

\section{A. The Americans with Disabilities Act ("ADA")}

One avenue for individuals with mental illness to sue for a perceived wrong is the Americans with Disabilities Act ("ADA"). The ADA is a Federal civil rights law which provides Federal civil rights protections to individuals with disabilities similar to those provided to individuals on the basis of race, color, sex, national origin, age, and religion. ${ }^{77}$

\footnotetext{
http://www.newyorker.com/magazine/2015/02/02/son-deceased [https://perma.cc/Q26L-SXVN].

76 Teplin, supra note 27.

77 United States Department of Justice Civil Rights DIVISION, https://www.ada.gov/ada_intro.htm , (last visited Apr. 17, 2017). [https://perma.cc/2SY2-3KLT]
} 
Congress intended for the ADA to "provide a clear and comprehensive national mandate for the elimination of discrimination against individuals with disabilities." 78 Under the ADA, the term 'disability' means: "(a) a physical or mental impairment that substantially limits one or more of the major life activities of such [an] individual; (b) a record of such an impairment; or (c) being regarded as having such an impairment."79 A substantial portion of individuals with mental illness, as discussed in this Note, would fall under the description provided by the ADA since 1) their mental illness limits one or more major life activities; 2) they have diagnosed mental illness; 3) and are generally regarded as having such impairment. ${ }^{80}$

Under Title II of the ADA, "no qualified individual with a disability shall, by reason of such disability, be excluded from participation in or be denied the benefits of the services, programs, or activities of a public entity, or be subjected to discrimination by any such entity." 81 A "public entity" is specified by the ADA to include "any State or local government; any department, agency, special purpose district, or other instrumentality of a State or States or local government." 82 Unlike the Rehabilitation Act, ${ }^{83}$ which only applies to agencies receiving federal funding, the ADA applies to all law enforcement agencies ${ }^{84}$ by the express

7842 U.S.C.S. § 12101(1) (2009)

7942 U.S.C.S. § 12102 (2009).

${ }^{80} \mathrm{Id}$.

8142 U.S.C.S. § 12132 (2017).

8242 U.S.C.S. § 12131(1)(A-B) (2017).

8329 U.S.C.S § 701: Rehabilitation Act of 1973; See also Allison v. Dep't of Corrections, 94 F.3d 494, 497 ( $8^{\text {th }}$ Cir. 1996) (stating, "cases interpreting either [the Rehabilitation Act or the ADA] are applicable and interchangeable.").

${ }^{84}$ See, e.g., Mohney v. Penn., 809 F.Supp.2d 384, 393, (W.D. Pa. 2011) (Unlike potential Eleventh Amendment barriers in $\S 1983$ causes of action against states and their respective police agencies for 
language of the statute because the agencies are programs of state or local government. ${ }^{85}$ Law enforcement agencies are required to make reasonable modifications in their policies, practices, and procedures that are necessary to ensure accessibility for individuals with disabilities. ${ }^{86}$ The ADA affects almost every area of law enforcement including: "receiving citizen complaints; interrogating witnesses; arresting, booking, and holding suspects; operating telephone (911) emergency centers; providing emergency medical services; enforcing [the] law; and various other duties." 87 As the court noted in Schorr v. Borough of Lemoyne, "nothing in the statute, regulations, or legislative history suggests any exceptions to the Act [ADA] for certain police activities." 88

\section{Causes of Action Under Title II of the ADA}

Under Tile II of the ADA there are two prevailing causes of action against law enforcement. ${ }^{89}$ They include "wrongful

constitutional violations, causes of action pursuant to the ADA do not have such concerns because "[t]here is no question that Congress expressed its unequivocal intent to abrogate state sovereign immunity when it enacted Title II of the ADA. See 42 U.S.C. § 12202 (providing that "[a] State shall not be immune under the [E]leventh [A]mendment to the Constitution of the United States from an action in Federal or State court of competent jurisdiction for a violation of this chapter".)).

${ }^{85} 29$ U.S.C. $\S 701$ et seq.

${ }^{86}$ U.S. DeP'T OF Justice: Civil Rights Div., DisABility Rights Section, COMmONLy AsKed Questions About the AmericANS With

DisABILITIES ACT AND LAW ENFORCEMENT (2006), https://www.ada.gov/q\%26a_law.htm [https://perma.cc/726V-PF88]

${ }^{87} I d$.

${ }^{88}$ Schorr v. Borough of Lemoyne, 243 F.Supp.2d 232, 236, (M.D. Pa. 2003).

${ }^{89}$ Martha S. Stonebrook, Title II of the Americans with Disabilities Act: The Potential for Police Liability and Ways to Avoid It, 73 The Police Chief 9 (September 2006). 
arrest" 90 and "failure to make a reasonable accommodation during arrest." 91 While a "failure-to-train" cause of action has also been pursued in federal court, it is not as common or recognized. ${ }^{92}$ Additionally, not all courts that have addressed these issues have recognized all of these causes of action. ${ }^{93}$ Generally, in order to state a claim under Title II of the ADA, a plaintiff must establish 1) that they are a qualified individual with a disability; ${ }^{94}$ 2) that they were either excluded from participation in or denied the benefits of some public entity's services, programs, or activities, or were otherwise discriminated against by the public entity; and 3) that such exclusion, denial of benefits, or discrimination was by reason of the plaintiff's disability. ${ }^{95}$

\section{a. Wrongful arrest}

A wrongful arrest cause of action presents itself when "police wrongly arrest someone with a disability because they misperceive the effects of that disability as criminal activity" when the activity is actually lawful. ${ }^{96}$ In Gohier $v$. Enright, the Tenth Circuit noted that courts often rely on the ADA's legislative history to conclude that a person with a

90 See Gohier v. Enright, 186 F.3d 1216, 1220 (10th Cir. 1999); Jackson v. Town of Sanford, 1994 WL 589617 (D.Me. Sept. 23, 1994); Orr v. California Highway Patrol, 2015 WL 848553 (E.D. Cal. 2015); Lewis v. Truitt, 960 F.Supp. 175, 178 (S.D. Ind. 1997).

${ }^{91}$ Stonebrook, supra note 91; See also Gohier v. Enright, 186 F.3d 1216, 1222 (10th Cir. 1999); Sudac v. Hoag, 378 F. Supp. 2d 1298 (D. Kan. 2005).

${ }^{92}$ Stonebrook, supra note 91.

${ }^{93} I d$.

${ }^{94}$ Cf. Sheehan v. City and Cty of S.F., 743 F.3d 1211, 1232 (9th Cir. 2014) (includes four factors for establishing a claim by separating "individual with a disability" and "qualified" into two factors).

${ }^{95}$ Gohier v. Enright, 186 F.3d 1216, 1219 (10th Cir. 1999).

${ }^{96} \mathrm{Id}$. at 1220 . 
disability can state a claim for such mistreatment. ${ }^{97}$ The applicable text reads, "persons who have epilepsy and a variety of other disabilities ... are inappropriately arrested and jailed because police officers have not received proper training ... [s]uch discriminatory treatment based on disability can be avoided by proper training." 98

For a wrongful arrest cause of action, Jackson v. Town of Sanford presents what amounts to a textbook example. ${ }^{99}$ There, a driver was arrested for operating a motor vehicle while intoxicated. ${ }^{100}$ However, as opposed to being intoxicated, the arresting officer had confused the driver's physical symptoms as the result of a stroke as signs of intoxication. ${ }^{101}$ In sum, many courts that have addressed wrongful arrest claims have determined that it is clear by the legislative history that these types of claims were precisely what was contemplated in the legislation's drafting and courts have applied this cause of action as such. ${ }^{102}$

\section{b. Reasonable accommodation during arrest}

The fundamental question for a reasonable accommodation cause of action is whether Title II applies to

${ }^{97}$ Id.

${ }^{98}$ Id. at 1221 (quoting H.R.Rep. No. 101-485, pt. III (1990)).

99 Jackson v. Town of Sanford, No. 94-12-P-H, 1994 WL 589617 (D. Me. Sept. 23, 1994) (resting its decision in part on the legislative history of the ADA, the court denied the town's motion for summary judgment).

${ }^{100}$ See id.

${ }^{101} I d$.

102 See Gohier v. Enright, 186 F.3d 1216, 1220 (10th Cir. 1999); Jackson v. Town of Sanford, No. 94-12-P-H, 1994 WL 589617 (D. Me. Sept. 23, 1994); Orr v. California Highway Patrol, No. 2:14-585 WBS EFB, 2015 WL 848553 (E.D. Cal. Feb. 26, 2015); Lewis v. Truitt, 960 F.Supp. 175, 178 (S.D. Ind.1997). 
arrests. ${ }^{103}$ On this question, the majority of circuits that have addressed the question agree that it does. ${ }^{104}$ However, the Fourth, Ninth, and Eleventh Circuits, which have held that Title II applies to arrests, also consider exigent circumstances in their ADA reasonableness analysis. ${ }^{105}$ This Note began with brief facts from City and County of San Francisco v. Sheehan. ${ }^{106}$ There, Sheehan pursued a reasonable accommodation cause of action under Title II of the ADA. ${ }^{107}$ She alleged, inter alia, that "the officers failed to reasonably accommodate her disability by forcing their way back into her room without taking her mental illness into account and without employing" alternative tactics, which could have led to a more peaceful resolution. ${ }^{108}$

The Supreme Court granted certiorari in the Sheehan case on the first question presented of whether Title II of the ADA "requires law enforcement officers to provide accommodations to an armed, violent, and mentally ill suspect in the course of bringing the suspect into custody." "109 However, the Court believed that San Francisco would argue that "Title II does not apply to an officer's on-the-street responses to reported disturbances or other similar incidents, whether or not those calls involve subjects with mental disabilities, prior to the officer's

${ }^{103}$ Sheehan v. City and Cty of S.F., 743 F.3d 1211, 1232 (9th Cir. 2014).

${ }^{104} \mathrm{Id}$.

${ }^{105}$ E.g., Sheehan v. City and Cty of S.F., 743 F.3d 1211, 1232 (9th Cir. 2014); Bircoll v. Miami-Dade Cty, 480 F.3d 1072 (11th Cir. 2007); Waller ex rel. Estate of Hunt v. City of Danville, 556 F.3d 171, 175 (4th Cir. 2009). (The Tenth Circuit has also applied Title II to arrests, see: Goshier v. Enright, 186 F.3d 1216 (10th Cir. 1999).

${ }^{106}$ See supra Part I.

${ }^{107}$ City \& Cty. of S.F. v. Sheehan, 135 S. Ct. 1765, 1771 (2015).

${ }^{108}$ Sheehan v. City \& Cty. of S.F., 743 F.3d 1211, 1232 (9th Cir. 2014).

${ }^{109}$ City \& Cty. of S.F. v. Sheehan, 135 S. Ct. 1765, 1772 (2015). 
securing the scene and ensuring that there is no threat to human life." 110 Instead, San Francisco chose to rely on a different argument than it presented at the Ninth Circuit and effectively conceded that the relevant provision of the ADA "may requir[e] law enforcement officers to provide accommodations to an armed, violent, and mentally ill suspect in the course of bringing the suspect into custody." 111 Therefore, since San Francisco, the United States as amicus curiae, and Sheehan all accepted that the ADA applies to arrests, the Court decided to not answer the question with a definitive decision. ${ }^{112}$

As Justice Scalia noted in his dissent, the circuits are in conflict on this question. ${ }^{113}$ The Fifth and Sixth Circuits have held that Title II does not apply, ${ }^{114}$ and the Fourth, Ninth, Tenth and Eleventh Circuits have held, or have at least indicated, that Title II does apply to arrests. ${ }^{115}$ Thus, while a failure to make reasonable accommodation under Title II of the ADA is a viable cause of action, the Supreme Court has yet to speak as to whether a reasonable accommodation is

${ }^{110} I d$. (emphasis original).

${ }^{111}$ Id. at 1773 (emphasis original) ("Having persuaded us to grant certiorari, San Francisco chose to rely on a different argument than what it pressed below.")

${ }^{112} I d$.

113 City \& Cty. of S.F. v. Sheehan, 135 S. Ct. 1765, 1778 (2015) (Scalia, J., dissenting)

${ }^{114}$ See Hainze v. Richards, 207 F.3d 795 (5th Cir. 2000); Thompson v. Williamson County, 219 F.3d 555 (6th Cir. 2000) (both courts held that reasonable accommodations are not required when the suspect the police are attempting to arrest creates an exigency by threatening officers or civilians).

115 See Waller ex. Rel. Estate of Hunt v. City of Danville, 556 F.3d 171, 175 (4th Cir. 2009); Sheehan v. City \& Cty. of S.F., 743 F.3d 1211, 1232 (9th Cir. 2014), overruled by City \& Cty. of S.F. v. Sheehan, 135 S. Ct. 1765 (2015); Gohier v. Enright, 186 F.3d 1216, 1221 (10th Cir. 1999); Bircoll v. Miami-Dade County, 480 F.3d 1072 (11th Cir. 2007). 
necessary when apprehending a potentially dangerous individual with mental illness.

In Sheehan, the Supreme Court also declined to answer another important question in regard to the ADA - whether a public entity can be held liable for damages under Title II for an arrest made by its police officers. ${ }^{116}$ As the Court explained, "[o]nly public entities are subject to Title II." 117 Both Sheehan and the City and County of San Francisco agreed that a "[public] entity can be held vicariously liable for money damages for the purposeful or deliberately indifferent conduct of its employees." "118 Even after noting that it has never decided whether that position is correct, the Court decided not to answer the question because of the absence of adversarial briefing on the subject. ${ }^{119}$

\section{c. Failure-to-train}

A failure-to-train cause of action under Title II of the ADA is both less employed and less recognized than other causes of action. ${ }^{120}$ Under a failure-to-train cause of action, an individual claims that a municipality failed "properly train its police officers to peacefully respond to persons with disabilities."121 In determining that plaintiffs stated an

116 Sheehan, 135 S. Ct. at 1773-74 ("Our decision not to decide whether the ADA applies to arrests is reinforced by the parties' failure to address a related question: whether a public entity can be liable for damages under Title II for an arrest made by its police officers").

${ }^{117} I d$. at 1773; see, e.g., Pa. Dep't of Corrs. v. Yeskey, 524 U.S. 206, 208 (1998).

118 Sheehan, 135 S. Ct. at 1773-74

${ }^{119}$ Id. at 1774.

120 See Scchetti v. Gallaudet University, 181 F.Supp.3d 107, 130 (D.C. Cir. 2016) ("As the District points out, however, several district courts outside this jurisdiction have been presented with the question and have either declined to recognize the existence of such a claim or avoided addressing the question.")

${ }^{121}$ Hogan v. City of Easton, 2004 WL 1836992, (E.D. Pa. Aug. 17, 2003). 
actionable failure-to-train claim under the ADA, the Schorr v. Borough of Lemoyne court explained:

Although to the lay reader this language may suggest only commonly available and publically shared accommodations such as parks, playgrounds, and transportation, the Act in no way limits the terms "services, programs, or activities," and appears to include all core functions of government. Among the most basic of these functions is the lawful exercise of police powers, including the appropriate use of force by government officials acting under color of law. Plaintiffs allege that these essential government functions are activities covered by the ADA and that the failure of Defendants to properly train the police for peaceful encounters with disabled persons caused decedent Schorr to be discriminated against and excluded from these government services. Nothing in the language of the statute suggests that the ADA does not extend to this type of governmental activity. ${ }^{122}$

While a failure-to-train cause of action is not a generally accepted cause of action under Title II of the ADA, ${ }^{123}$ its

${ }^{122}$ Schorr v. Borough of Lemoyne, 243 F. Supp. 2d 232, 235 (M.D. Pa. 2003).

${ }^{123}$ Cf. Sheehan v. City \& Cty. of S.F., 743 F.3d 1211, 1232 (9th Cir. 2014) (noting that "[c]ourts have recognized at least two types. . . wrongful arrest ... [and] reasonable accommodation"); But see Roberts v. City of Omaha, 723 F.3d 966, 976 (8th Cir. 2013) (holding that plaintiff's failure-to-train claim could proceed under the ADA if the plaintiff showed the defendant's "deliberate indifference to his alleged right to be free from discrimination.") 
legislative history leaves the door open for a successful suit. ${ }^{124}$ Indeed, the House Judiciary Committee stated, "'in order to comply with the non-discrimination mandate, it is often necessary to provide training to public employees about disability... discriminatory treatment based on disability can be avoided by proper training." "125 Training should certainly qualify amongst "reasonable modifications in policies, practices, or procedures when the modifications are necessary to avoid discrimination on the basis of disability, unless the public entity can demonstrate that making the modifications would fundamentally alter the nature of the service, program, or activity." ${ }^{126}$ Further, as the Ninth Circuit held, the ADA applies broadly to police "services, programs, or activities" 27 or, in short, "anything a public entity does." ${ }^{28}$ As such, a failure-to-train cause of action should be both more widely employed and more generally accepted.

\section{Department of Justice ADA Enforcement}

Individuals with mental illness can also pursue enforcement of the ADA through the Department of Justice ("DOJ") by filing a complaint. ${ }^{129}$ The DOJ is tasked with

${ }^{124}$ See Schorr v. Borough of Lemoyne, 243 F. Supp. 2d 232, 236 (M.D. Pa. 2003) (discussing the merits of a broad interpretation of Title II of the ADA through examination of its legislative history).

${ }^{125}$ Id. (quoting H.R. REP. No. 101-485, pt. 3, at 50 (1990)).

12628 C.F.R. $\S 35.130$ (b)(7)(i) (2017).

${ }^{127}$ Sheehan v. City \& Cty. of S.F., 743 F.3d 1211, 1232 (9th Cir. 2014) (quoting 42 U.S.C. § 12132 (2016)). 2001)).

${ }^{128} I d$. (quoting Lee v. City of L.A., 250 F.3d 668, 691 (9th Cir.

${ }^{129}$ See How to File an ADA Complaint with the U.S. Department of Justice, U.S. DEP'T JUST.: C.R. DIVISION, http://www.ada.gov/filing_complaint.htm [https://perma.cc/U8Y9AQLE] (last visited Mar. 20, 2017). 
enforcing the $\mathrm{ADA}$ and can conduct compliance reviews to determine an entity's compliance with Title II. ${ }^{130}$ Although the general rules governing lawsuits are brought on behalf of the Federal government, the DOJ must first conduct negotiations to settle a dispute. ${ }^{131}$ However, if settlement attempts fail and compliance with Title II is not achieved, the DOJ may file a lawsuit in federal court. ${ }^{132}$ If the DOJ decides to bring suit, it may pursue compensatory damages and civil penalties authorized under the ADA, which include $\$ 55,000$ for the first violation and $\$ 110,000$ for any subsequent violation. ${ }^{133}$

\section{B. $\$ 1983$ Causes of Action Under the U.S. Constitution}

\section{Municipal Liability Under $\$ 1983$}

While a comprehensive explanation of 42 U.S.C. $§ 1983$ is beyond the scope of this Note, the statute's origin and evolution are important in order to understand its employment against municipalities and law enforcement officers today. Originating in the $\mathrm{Ku}$ Klux Klan Act of $1871^{134}$, one purpose of the Act was to "afford a federal right in federal courts because, by reason of prejudice, passion, neglect, intolerance or otherwise, state laws might not be enforced and ... rights . . . guaranteed by the Fourteenth

\footnotetext{
${ }^{130}$ Stonebrook, supra note 91.

${ }^{131}$ Department of Justice ADA Responsibilities: ADA Enforcement, U.S. DEP'T JUST.: http://www.ada.gov/enforce_footer.htm [https://perma.cc/XC93PHWF] (last visited Mar. 20, 2017).

${ }^{132} \mathrm{Id}$; see also 42 U.S.C. $§ 12133$ (2016).

${ }^{133}$ Department of Justice ADA Responsibilities: ADA Enforcement, supra note 125.

${ }^{134} \mathrm{Ku}$ Klux Klan Act of 1871, Pub. L. No. 42-22, 17 Stat. 13 (codified as amended in scattered sections of 42 U.S.C.).
} 
Amendment might be denied by state agencies."135 42 U.S.C. $§ 1983$ states, in relevant part:

Every person who, under color of any statute, ordinance, regulation, custom, or usage, of any State or Territory or the District of Columbia, subjects, or causes to be subjected, any citizen of the United States or other person within the jurisdiction thereof to the deprivation of any rights, privileges, or immunities secured by the Constitution and laws, shall be liable to the party injured in an action at law, suit in equity, or other proper proceeding for redress .... 136

The Eleventh Amendment bars a state from suit. ${ }^{137}$ However, a state officer, in his official capacity, can be sued for prospective or injunctive relief by what is referred to as the "legal fiction" of Ex Parte Young, ${ }^{138}$ despite the fact that a suit against a state official in their official capacity represents nothing more than a suit against the government entity itself. ${ }^{139}$ Municipalities and local governments are within the meaning of "persons" for the purposes of $\S 1983$

${ }^{135}$ Monroe v. Pape, 365 U.S. 167, 180 (1961).

13642 U.S.C.A. § 1983 (1996).

${ }^{137}$ U.S. CONST. amend. XI ("The Judicial power of the United States shall not be construed to extend to any suit in law or equity, commenced or prosecuted against one of the United States by Citizens of another State, or by Citizens or Subjects of any Foreign State").

${ }^{138}$ Ex Parte Young, 209 U.S. 123 (1908); see also Verizon Md., Inc. v. Pub. Serv. Comm'n of Md., 535 U.S. 635, 649 (2002) (Kennedy, J., concurring) (Justice Kennedy referring to Ex Parte Young as "legal fiction").

${ }^{139}$ Ex Parte Young, 209 U.S. 123 (1908). 
and can be sued for both prospective relief and damages. ${ }^{140}$ In order for a municipality to be liable under $\S 1983$, any harm must be the result of an official policy, ordinance, regulation, or decision. ${ }^{141}$ Law enforcement action constitutes "under color of state law" generally because it is "possessed by virtue of state law and made possible only because the wrongdoer is clothed with the authority of state law." 142

\section{Failure-to-train}

Individuals with mental illness can also sue under 42 U.S.C. $\S 1983$ for violation of their constitutional rights on the theory of failure-to-train. ${ }^{143}$ The thrust of a failure-totrain $\S 1983$ claim is that "if a concededly valid policy is unconstitutionally applied by a municipal employee, the city is liable if the employee has not been adequately trained and the constitutional wrong has been caused by that failure to train." 144

The landmark case in this area of the law is City of Canton v. Harris, where the Supreme Court recognized the theory of failure-to-train liability as applied to law enforcement. ${ }^{145}$ There, an individual had been arrested and denied adequate first-aid treatment. ${ }^{146}$ She sued on the basis

140 See Monell v. Dep't of Social Serv. of N.Y., 436 U.S. 658, 690 (1978) ("Our analysis of the legislative history of the Civil Rights Act of 1871 compels the conclusion that Congress did intend municipalities and other local government units to be included among those persons to whom § 1983 applies").

${ }^{141} \mathrm{Id}$. at 694 .

142 West v. Atkins, 487 U.S. 42, 49 (1988) (quoting United States v. Classic, 313 U.S. 299, 326 (1941)).

143 See Connick v. Thompson, 563 U.S. 60-61 (2011).

${ }^{144}$ City of Canton v. Harris, 489 U.S. 378, 387 (1989).

${ }^{145} \mathrm{Id}$. at 388 .

${ }^{146} I d$. at $381-82$. 
that her rights under the Due Process Clause of the Fourteenth Amendment had been denied and that the police department had failed to train its officers in order to accommodate for an expected need. ${ }^{147}$ The Court held that "the inadequacy of police training may serve as the basis for $\S 1983$ liability only where the failure to train amounts to deliberate indifference to the rights of persons with whom the police come into contact." 148

The Court explained that in failure-to-train cases, they first look to "whether the training program is adequate; and if it is not," they decide as to whether the inadequacy of the training program "can justifiably be said to represent "city policy." 149 While the Court noted the improbability that a municipality would actually have an official policy of not training its employees, it explained that considering the duties and challenges officers face, if officers fail to receive appropriate training and the absence of such training is likely to result in the violation of constitutional rights, then the municipality is deemed "to have been deliberately indifferent to the need." 150 Additionally, the Court explained the particular difficulty of the fact-finder determining whether an injury would have been avoided had the "employee been trained under a program that was not deficient in the identified respect," but ultimately concluded, "judge and jury, doing their respective jobs, will be adequate to the task." ${ }^{151}$ Considering the often unpredictable nature of

${ }^{147} I d$. at $381-83$.

${ }^{148} \mathrm{Id}$. at 388 .

${ }^{149} \mathrm{Id}$. at 390 .

${ }^{150} \mathrm{Id}$.

${ }^{151} I d$. at 391.

Predicting how a hypothetically well-trained officer would have acted under the circumstances may not be an easy task for the factfinder, particularly since matters of judgment may be involved, and since officers who are well trained are not free from error 
law enforcement encounters with individuals with mental illness, particularly severe mental illness, a fact-finder arriving at such a determination would indeed be a difficult proposition, but not impossible.

In Board of Commissioners v. Brown, the Supreme Court held that an action must amount to deliberate indifference in so far as the municipality knew, or should have known, that a violation of a particular constitutional right would occur. ${ }^{152}$ The Court previously discussed roughly the same standard in City of Canton v. Harris. ${ }^{153}$ There, the Court used law enforcement training for lethal force as an example and discussed the need to train officers in the constitutional limitations on the use of deadly force. ${ }^{154}$ The Court concluded that this type of training "can be said to be 'so obvious,' that failure to do so could be properly be characterized as 'deliberate indifference' to constitutional rights." 155 Similar to the first-aid training involved in City of

and perhaps might react very much like the untrained officer in similar circumstances.

152 Bd. of Cnty. Comm'rs v. Brown, 520 U.S. 397, 404 (1997). The Court stated also

[a]s our $\S 1983$ municipal liability jurisprudence illustrates, however, it is not enough for a $§ 1983$ plaintiff merely to identify conduct properly attributable to the municipality. The plaintiff must also demonstrate that, through its deliberate conduct, the municipality was the 'moving force' behind the injury alleged. That is, a plaintiff must show that the municipal action was taken with the requisite degree of culpability and must demonstrate a direct causal link between the municipal action and the deprivation of federal rights (emphasis original).

${ }^{153}$ City of Canton v. Harris, 489 U.S. 378, 389-93 (1989).

${ }^{154}$ Id. at 390 n. 10.

${ }^{155}$ Id.; see also Gold v. City of Miami, 151 F.3d 1346, 1351-52 (11th Cir. 1998) (finding "no obvious need" that officers must be trained regarding a disorderly conduct statute and the proper response to handcuff complaints). 
Canton or the analogy of use-of-force training discussed by the Court, ${ }^{156}$ encountering an individual with mental illness is both a frequent and expected occurrence for law enforcement agencies. ${ }^{157}$ With estimates of up to $10 \%$ of police calls involving individuals who have mental illness, ${ }^{158}$ and the frequency of police action shootings in such interactions, ${ }^{159}$ it becomes difficult to imagine that police departments are unaware of the particular challenges posed and the benefits that can come from appropriate training.

\section{Indemnification of Excessive or Unreasonable Force Claims}

Even if the municipality is not directly implicated by a failure-to-train cause of action, municipalities may be implicated in an excessive or unreasonable force suit against an officer or officers under $\S 1983 .{ }^{160}$ While the Supreme Court rejected respondeat superior liability against municipalities for constitutional violations under $\S 1983$ in Monell v. Dep't of Soc. Servs. of City of New York, ${ }^{161}$ municipalities can still be held liable by way of

${ }^{156}$ See also Popow v. City of Margate, 476 F.Supp. 1237, 1246-47 (D.N.J. 1979) (discussing failure-to-train as applied to use of force where a police department's only continuing training was every six months at a shooting range, and the court noted that a fact finder could find the department's training "grossly inadequate").

${ }^{157}$ See supra Part II.

${ }^{158}$ Watson \& Angell, supra note 24, at 30.

${ }^{159}$ See Lowery et al., supra note 67.

160 See, e.g., Graham v. Connor, 490 U.S. 386, 388, 394 (1989).

${ }^{161}$ See Monell v. Dep't of Soc. Servs. of City of New York, 436 U.S. 658, 694, 707 (1978) (“'A municipality] may not be sued under $§ 1983$ for an injury inflicted solely by its employees or agents"). 
indemnification. ${ }^{162}$ Because many states have indemnification statutes, the municipality itself often bears the cost of a financial award when a police officer violates the constitutional rights of an individual with mental illness, even without an official policy that contributed to the ultimate injury. ${ }^{163}$ In one study that examined settlements and judgments awarded against law enforcement agencies between 2006 and 2011, the data suggests that police officers were personally responsible for just $0.02 \%$ of over $\$ 730$ million. ${ }^{164}$ Even when an indemnification statute did not exist, or in the alternative, even when a statute expressly prohibited indemnification, officers were still not required to contribute to settlements and judgments against them. ${ }^{165}$

Indemnification then becomes an important aspect of any $\S 1983$ cause of action because while municipalities are not directly accountable for their employee's actions, they still likely bear the burden of any financial award. In sum, even when a $\S 1983$ cause of action does not directly implicate a municipality, because indemnification of an individual officer is a likely result, municipalities are effectively held to a form of vicarious liability.

162 Peter H. Schuck, Suing Government: Citizen ReMEdies FOR OfFICIAL WRONGs 86-87 (Yale University Press, 1983).

${ }^{163} I d$. ("Most states provide some form of indemnification or other protection against adverse judgments or settlements . . ..").

164 Joanna C. Schwartz, Police Indemnification, 89 N.Y.U. L. REV. 885, 890, 960 (2014) (Discussing the conclusions of a wide survey, which included police departments of all sizes. "this Article reveals that officers almost never contribute anything to settlements and judgment in police misconduct suits").

${ }^{165} I d$. at 960 ("officers were not required to contribute to settlements and judgments even when applicable law prohibited indemnification"). 


\section{A FEASIBLE SOLUTiON}

With the preceding discussion about how municipalities can be held liable by way of the ADA or a constitutional violation, ${ }^{166}$ one potential solution for municipalities is to utilize Crisis Intervention Teams (“CIT").

\section{A. What is CIT?}

CITs have become a widespread and promising law enforcement mental health training program. CIT training is available in various versions but the Memphis Model has become particularly successful, being dubbed the "gold standard."167 The Memphis Model originated in the aftermath of a police action shooting of a mentally ill man in Memphis, Tennessee. ${ }^{168}$ Like so many cities around the country, Memphis saw an increase in police involvement with individuals with mental illness after deinstitutionalization. ${ }^{169}$ A 'blue ribbon' mayoral commission consisting of mental health professionals and the local law enforcement community was tasked with examining training in mental health for Memphis' officers and produced an early version of what it is today. ${ }^{170}$

CIT is more than just a training course, however, because it employs a collaborative approach, designed to help police

${ }^{166}$ See supra Part III.

${ }^{167}$ Michael T. COMPTON ET AL., THE CRISIS INTERVENTION TEAM (CIT) Model of Collaboration BetweEn LaW ENFORCEMENT AND Mental Health 17 (Nova Science Publishers, Inc., 2011).

168 Justice Evelyn Lundberg Stratton, What is a CIT? Why Do You Need One In Your Community?, 32 CAP. U. L. REV. 1015, 1015 (2004) (interview with Dr. Mark R. Munetz) [hereinafter Stratton].

${ }^{169}$ COMPTON ET AL., supra note 169, at 13.

${ }^{170}$ Interview with Dr. Richard T. Dupont, Professor \& Clinical Psychologist, Dep't of Criminology \& Criminal Justice, U. of Memphis (January 6, 2016). 
officers identify and deal with individuals with mental illness. ${ }^{171}$ In addition to law enforcement, this collaboration involves: "NAMI (National Alliance for the Mentally Ill), mental health consumers, mental health providers, and local universities." 172 At the time of its inception,

Family members believed that the [police] officers lacked sensitivity, did not understand mental illnesses or the nature of a mental health crisis, and therefore made the situation worse. . . . Not only were family members reluctant or afraid to request assistance from the police, but those individuals with mental illnesses who were victims of crimes had also become fearful of calling the police for help. As a result of sheer desperation, family members of these individuals initiated a mission for police change, becoming proactive by meeting with law enforcement administrators, county officials, and city council members. ${ }^{173}$

The core elements of the program emphasize officer safety and the safety of individuals with mental illness, while finding mental health solutions instead of criminal justice solutions. ${ }^{174}$ Rather than traditional use of force, CIT employs crisis de-escalation training involving role-playing

\footnotetext{
${ }^{171}$ Stratton, supra note 170 , at 1015.

${ }^{172} I d$. at 1016.

${ }^{173}$ COMPTON ET AL., supra note 169, at 13-14.

174 The UnIVERsity OF MeMPhIS: SCHOOL OF URBAN AFFAIRS AND Public Policy, DePARTMENT OF CRIMINOLOGY AND CRIMINAL JuSTICE CIT CENTER, Crisis Intervention Team Core Elements, at 3 (2006), http://www.cit.memphis.edu/information_files/CoreElements.pdf [https://perma.cc/Q5CN-TGWV] (last visited Nov. 3, 2015).
} 
scenarios and revolves around a community-based program involving police, health professionals, and community leaders. ${ }^{175}$ As a result of Memphis' multifaceted approach, CIT's forty-hour curriculum "is the most comprehensive police officer mental health training program in the country." 176

\section{B. CIT Officers}

Within a police department, CIT programs consist of law enforcement officers, dispatchers and a CIT coordinator. ${ }^{177}$ CIT officers should be handpicked officers who have a "high emotional IQ," low use of force incidences, and a low number of complaints. ${ }^{178}$ These officers usually handle CIT calls in addition to regular patrol calls. ${ }^{179}$ While patrol officers already possess a basic understanding of and have training in safety skills, CIT training develops "new verbal de-escalation techniques that enable them to more effectively approach a crisis situation involving an individual with a mental illness." 180 In addition to the development of verbal de-escalation techniques, programs also include lectures, "on-site visitation and exposure to mental health facilities, interaction with individuals with

175 Id. at 14.

176 Pauly, supra note 48.

${ }^{177}$ COMPTON ET AL., supra note 169, at 33.

178 Woody, supra note 70; see also COMPTON ET AL., supra note 169, at 33 (finding that officers "should be selected according to specific criteria (i.e., work history and an interview)").

179 Woody, supra note 70; see also COMPTON ET AL., supra note 169, at 33 ("CIT officers should maintain their patrol duties while accepting new duties and skills through CIT training, and assume the additional responsibilities of designated responder and lead officer in mental health crisis events").

${ }^{180}$ COMPTON ET AL., supra note 169, at 34. 
mental illnesses," scenario-based training, and occasionally a "ride-along" with a current CIT officer. ${ }^{181}$

Police dispatchers are also an important aspect of CIT programs. Dispatchers receive specialized training similar to CIT officers and receive particularized instruction that addresses the proper method for receiving and dispatching officers to calls involving individuals with mental illness. ${ }^{182}$ After identifying a call that involves individuals with mental illness, the dispatcher relays the call to a CIT officer who responds to the scene. ${ }^{183}$ This combination can be highly effective in warning officers of a potentially dangerous situation.

One recent example of the importance of incorporating police dispatchers into CIT programs occurred in Chicago, Illinois. In December 2015, Quintonio LeGrier, who suffers from mental illness, was shot by a police officer following a frantic incident. ${ }^{184}$ Quintonio was a nineteen-year-old student at Northern Illinois University who was home on winter break. ${ }^{185}$ Quinterio had a recent history of mental health problems and was behaving erratically when, at 4:18 A.M., he called the police, stating ". . . I need an officer. . . ."186 Because Quinterio was unable or unwilling to provide the dispatcher with more information, the dispatcher told

181 Id.

182 Id.; see also Woody, supra note 70 ("Your dispatchers know what to ask to determine if this is in fact a call for mental illness").

183 COMPTON ET AL., supra note 169, at 34 (discussing the importance of a dispatcher's ability to recognize behavior crisis events, and appropriately dispatching a CIT officer).

184 David Schaper, Claiming Emotional Trauma, Chicago Officer Countersues Victim's Estate, NAT'L PUB. RADIO (Feb. 10, 2016, 5:03 AM), http://www.npr.org/2016/02/10/466250515/claiming-emotionaltrauma-chicago-officer-countersues-estate-of-victim-he-shot [https://perma.cc/75DL-4U2R].

${ }^{185} \mathrm{Id}$.

${ }^{186}$ Id. 
him "if you can't answer the questions, I'm going to hang up" even after Quinterio repeated, "[ $t]$ here's an emergency." 187 The dispatcher ended the call. ${ }^{188}$ When a Chicago police officer arrived on scene, Quinterio emerged from his apartment and swung a bat at the officer, narrowly missing his head. ${ }^{189}$ After Quinterio swung twice more, the officer opened fire. ${ }^{190}$ The officer fired eight shots with six striking Quinterio-killing him. ${ }^{191}$ One of the stray bullets passed through the wall and killed the neighbor, fifty-five year-old Bettie Jones. ${ }^{192}$

This scenario provides a perfect example for a CIT program focused on training, not only the responding officer, but also the dispatcher. While admitting the unpredictable nature of these situations, a well-trained dispatcher, familiar with the signs of mental illness, would have been more likely to recognize the symptoms Quinterio displayed and taken appropriate measures. These actions would include dispatching a CIT trained officer and utilizing de-escalation techniques by phone.

Other important aspects of the program include mental health coordinators, advocacy coordinators, and mental health receiving facilities. Mental health coordinators are members of the local mental health community. ${ }^{193}$ Aside from serving in a leadership role in the program, mental health coordinators also act as the liaison between the mental health and law enforcement communities. ${ }^{194}$ The advocacy community "is comprised of advocates, family members,
${ }^{187} \mathrm{Id}$.
${ }^{188} I d$.
${ }^{189} \mathrm{Id}$.
${ }^{190} \mathrm{Id}$.
${ }^{191} \mathrm{Id}$.
${ }^{192} \mathrm{Id}$.
${ }^{193}$ COMPTON ET AL., supra note 169, at 34.
${ }^{194} \mathrm{Id}$. 
and individuals with mental illness." ${ }^{195}$ Their representative - the advocacy coordinator-is responsible for "operational components that include training, curriculum, and ongoing problem-solving." ${ }^{196}$ Finally, a designated emergency mental health receiving facility provides an alternative to jail and a point of emergency entry. ${ }^{197}$ Together, the various components of CIT programs have proven to be an effective tool in over 2700 communities across the country, ${ }^{198}$ or about $15 \%$ of police jurisdictions nationwide. ${ }^{199}$

\section{Results of Implementing CIT Training}

There is a wealth of material on the success of CIT training and empirical research as to its effectiveness. ${ }^{200}$ This research has evaluated various aspects of CIT's impact including police officers, individuals with mental illness or mental health "consumers," and CIT's impact on communities as a whole. ${ }^{201}$

CIT programs have shown promising results among officers trained in its de-escalation techniques, alternative problem solving methods, and overall mental health education. ${ }^{202}$ "Research has shown a reduction in officer bias towards individuals with mental health disabilities after

\footnotetext{
${ }^{195} I d$.

${ }^{196} I d$.

${ }^{197}$ Id. at 35.

198 Law Enforcement and Mental Health, NAMI, https:/www.nami.org/Get-Involved/Law-Enforcement-and-MentalHealth [https://perma.cc/VX8P-MZ9S] (last visited Apr. 17, 2017).

199 Watson \& Angell, supra note 24.

200 See e.g., COMPTON ET AL., supra note 169, at 41.

${ }^{201} \mathrm{Id}$. at $1,43-48$.

${ }^{202}$ Id. at 43-48.
} 
receiving CIT training," 203 that officers were more likely to indicate that they were well prepared in situations involving individuals with mental illness, ${ }^{204}$ and that CIT trained officers were less likely to resort to use-of-force than nonCIT officers. $^{205}$ Furthermore, evidence suggests an association between CIT implementation and a decrease in utilization of SWAT teams. ${ }^{206}$

\section{CIT and $\S 1983$}

In one example of a $\S 1983$ failure-to-train claim involving CIT, the parents of an individual with mental

203 Pamila Lew et al., Cal. Mental Health Servs. Auth., An Ounce of PREVEntion: LAW ENFORCEMENT TRAINING AND MENTAL $\begin{array}{llll}\text { HEALTH CRISIS } & \text { INTERVENTION } & 40 & \text { (2014), }\end{array}$ http://www.disabilityrightsca.org/pubs/CM5101.pdf [https://perma.cc/E4A3-TRRL].

204 Randy Borum et al., Police Perspectives on Responding to Mentally Ill People in Crisis: Perceptions of Program Effectiveness, 16 BEHAV. SCI. L. 393, $399 \quad$ (1998) http://scholarcommons.usf.edu/cgi/viewcontent.cgi?article=1567\&cont ext=mhlp_facpub [https://perma.cc/EZ6U-FFU7] (see Table 2. Asking officers if they prepared they felt to handle individuals with mental illness in crisis: Memphis CIT officers $=100 \%$, Memphis non-CIT officers $65 \%$, Knoxville non-CIT 78.1\%, Birmingham non-CIT officers $52 \%)$.

205 See Michael T. Compton et al., Surveys of Police Chiefs and Sheriffs and of Police Officers About CIT Programs, 66 PSYCHIATRIC SERVS. 7, 760-63 (2015) (finding that CIT-trained officers appeared to be less likely to revert to force in a situation involving psychotic agitation); see also Jennifer Skeem \& Lynne Bibeau, How Does Violence Potential Relate To Crisis Intervention Team Responses to Emergencies? 59 PSYCHIATRIC SERVS. 201, 204 (2008) (found that CIT officers used force in only $15 \%$ of encounters rated as high-violence risk, and that when they did use force, they generally relied on low-lethal methods).

${ }^{206}$ Randolph T. DuPont \& Sam Cochran, Police Response to Mental Health Emergencies-Barriers to Change, 28 J AM. ACAD. PSYCHIATRY L. 338, 344 (2000). 
illness brought suit against the City of Houston for, inter alia, failing to train its officers in CIT tactics. ${ }^{207}$ In Valle $v$. City of Houston, the parents of Esparza Valle had contacted the police because Esparza- "who had apparently been suffering from depression and anxiety in the preceding months"- locked himself in his family home and would not allow his parents to enter. ${ }^{208}$ After police arrived and negotiations with Esparza failed, officers on scene contacted CIT Officer Broussard, who then continued to attempt negotiations with Esparza, which again failed to produce results. ${ }^{209}$ Without consulting Officer Broussard, the other non-CIT officers received permission from their commander, Captain Williams, to enter the house and seize Esparza, even though he was not a suspect in any criminal activity, nor had he threatened the officers or himself. ${ }^{210}$ When the officers entered the home, they shot and killed Esparza after they claimed he had charged the officers with a hammer. ${ }^{211}$

Alleging that the City of Houston's training was inadequate, the Valles presented evidence of a 2004 proposal for additional mandatory CIT training, which the City chose not to implement. ${ }^{212}$ The proposal stated that CIT training is "a proven curriculum for helping officers safely de-escalate situations involving individuals in serious mental health crises," and "(1) that all patrol officers be required to complete twenty-four hours of CIT training, and (2) that all patrol sergeants be required to complete CIT training." ${ }^{213}$ The Fifth Circuit held that there was no evidence that the

\footnotetext{
${ }^{207}$ Valle v. City of Houston, 613 F.3d 536, 540 (5th Cir. 2010).

${ }^{208} I d$. at 539 .

${ }^{209} \mathrm{Id}$. at 540 .

${ }^{210} \mathrm{Id}$.

${ }^{211} \mathrm{Id}$.

${ }^{212} I d$. at 544 .

${ }^{213} \mathrm{Id}$. at $544-45$.
} 
City's failure to train officers in CIT tactics was the moving force in the decision to enter the home because Captain Williams, who made the determination to enter, was trained in CIT even though he was not personally on the scene. ${ }^{214}$ While CIT Officer Broussard was on scene but not consulted about entry, she later testified that she would not have disagreed with the decision. ${ }^{215}$

While the Fifth Circuit held that the City of Houston was not deliberately indifferent for its failure to train officers in CIT tactics and that there was no evidence that the City's failure to train officers in CIT tactics was the "moving force" behind the officer's decision to enter the home, the court did find that there was "sufficient evidence of causation to survive summary judgment with respect to the escalation of force after the officers' entry." 216 In doing so, the court pointed to the fact that there was no evidence that any of the officers, who actually entered the house, were CIT trained. $^{217}$ Additionally, the court looked to the Valles' expert witness, who stated that "there is a substantially greater likelihood that [Esparza] would [have] survived[d] if the officers going in there are the very best trained, best equipped, best prepared to deal with any kind of eventuality." 218 Ultimately, the case presented a factintensive inquiry which turned on evidence that the City of Houston actually had CIT officers and that those officers played an important role in the case. ${ }^{219}$

Valle v. City of Houston is a great example of the potential liability for municipalities that disregard the benefits of CIT tactics in dealing with individuals with

\footnotetext{
${ }^{214} I d$. at 546.

${ }^{215} \mathrm{Id}$.

${ }^{216} I d$. at 546-47.

${ }^{217} I d$.

${ }^{218} \mathrm{Id}$. at 546.

${ }^{219}$ See id.
} 
mental illness or do not utilize their CIT trained officers in an effective way.

\section{CONCLUSION}

First and foremost, law enforcement agencies and their respective municipalities should realize the particular challenges that individuals with mental illness often pose and the innovative and effective available training. Municipalities must acknowledge the potential liability they accept by failing to provide adequate mental health training. With mounds of data as to the frequency of lethal-force situations involving individuals with mental illness and the prevalence of their daily contact with law enforcement, the time has come where failing to train law enforcement officers to confront such events is simply unacceptable. The top priority for any police chief, commissioner, sheriff, or town marshal is the safety of their officers and their community. Mental health training for law enforcement advances both of those noble goals to the point of being a basic necessity.

Second, even though this Note primarily discussed municipalities, the states themselves possess the greatest tool in obtaining fundamental change through their allocation of funds. States can better prepare their officers by incorporating a CIT program (or a similar, forty hour or more program) into their respective law enforcement academies. ${ }^{220}$ Thus, all new police officers will have the

${ }^{220}$ Mellinger, supra note 59.

$[\mathrm{m}] \mathrm{y}$ first wish would be that the legislature just mandates that the forty hours be required at basic training. To me, that's the easiest and most costeffective. If the legislature wants to get serious about it - that's what they should do. There would be several of us who would stand in line supporting that. Short of 
training in mental illness they need before beginning their careers. Officers graduating academies return to police departments all over the state and could bring valuable mental health training and expertise with them. Larger police departments have the responsibility to hold CIT training and invite smaller, local police departments to participate in the training. This way, all new officers will be trained at the academy level, and the remaining untrained officers will be reduced by attrition.

States sit in the best position to fund mental health training for both state and local police departments. Legislatures can take meaningful steps to better prepare their officers and insulate their municipalities by appropriating adequate funding. This issue is simply too important to the safety of both police officers and citizens for budget concerns to play a prohibitive role.

Third, courts should increasingly hold municipalities accountable for failing to train their law enforcement officers. There is ample data on the necessity of such training. Minimal requirements no longer prove sufficient to ensure safety, and law enforcement agencies know, or should know, of the reality of that fact. Indeed, there is so much data that constitutional violations against individuals with mental illness should be deemed the "known or obvious consequence" of omitting sufficient mental health training. ${ }^{221}$ Not only should failure-to-train causes of action under 42 U.S.C. $\S 1983$ be increasingly recognized where the facts of the case prove appropriate, but the previously rarely recognized cause of action-failure-to-train under the ADA - should grow in prevalence as well. In addition to liability being the most effective way to ensure compliance,

that, my next wish would be that more police administrators, mayors, and town councils would get serious about it and just make the commitment locally.

${ }^{221}$ Bd. of Cnty. Comm'rs v. Brown, 520 U.S. 397, 410 (1997). 
such causes of action align with the express purposes of both $\S 1983$ and the ADA, to wit, the protection of civil rights.

Furthermore, in conducting a deliberate indifferent analysis for municipal liability with regard to its police training on mental illness, courts should not wait until that municipality has a pattern of constitutional violations in order to find the municipality deliberately indifferent to the constitutional rights of its citizens. The relevant data is easily available to every law enforcement agency across the country, and CIT programs or similar de-escalation training for mental illness drastically improve the likelihood of peaceful interactions with individuals with mental illness.

In conclusion, the solution to any nationwide problem is never simple and in order to reduce the number of injuries and fatalities to both police officers and civilians resulting from law enforcement encounters with individuals with mental illness, we, as a society, must employ a wide variety of solutions. First and foremost: municipalities should bear the low cost of providing adequate training mental health training to their law enforcement officers or bear the high cost of their failure. 